\title{
The Development of Inclusive Finance in Chongqing
}

\author{
Yi Li \\ Yangtze Normal University \\ Chongqing, China
}

\author{
Xin Wei \\ Yangtze Normal University \\ Chongqing, China
}

\begin{abstract}
The strategy of Rural Revitalization marks a new stage of urban and rural construction in China, and the development of inclusive finance can provide financial services and financial support for agricultural and rural development. Based on the theoretical analysis of inclusive finance and Rural Revitalization Strategy, this paper constructs an inclusive financial measurement index system from two dimensions of financial services and financial use and takes Chongqing as an example to measure the quality of inclusive financial development by using relevant data of financial development in Chongqing.
\end{abstract}

Keywords-Rural Revitalization Strategy; inclusive finance; measurement index; empirical research

\section{INTRODUCTION}

Based on the empirical results and relevant theories, this paper chooses industrial structure, urban-rural income gap and other indicators as explanatory variables to explore the impact of different factors on the development of inclusive finance. Empirical analysis shows that the increase of the proportion of primary industry inhibits the development of inclusive finance in Chongqing, while the income gap between urban and rural areas also inhibits the development of inclusive finance. Finally, combined with the empirical conclusions, the paper puts forward policy recommendations to vigorously develop inclusive finance and narrow the gap between urban and rural areas. The research conclusions have positive effects on optimizing inclusive financial development planning and promoting the implementation of Rural Revitalization Strategy.

\section{OVERVIEW OF RELEVANT THEORIES}

\section{A. The Concept of Inclusive Finance}

First, inclusive financial system was first proposed by the United Nations in 2005. Inclusive Financial, also known as "inclusive finance," is defined as a financial system that can provide financial services to the entire society and people at all levels. The proposal of inclusive finance in China was made at the Asian Micro-finance Forum in 2006. It is believed that inclusive finance is also of a commercial nature and can serve the entire society and people at all levels.

\section{B. Affecting Factors of Inclusive Finance}

The research on the influencing factors of inclusive finance has made a lot of research in the literature. The main factors include the level of economic development, the income gap between urban and rural areas, the industrial structure, and financial participation. Based on the previous research, this paper analyzes its impact on inclusive finance from these four aspects.

\section{PRESENT SituAtion OF INCLUSIVE FINANCE IN CHONGQING}

In recent years, the development of inclusive finance has received the attention of all parties in the society. The government has made positive attempts to promote the development of inclusive finance. Inclusive finance has been rapidly developed, and a series of achievements have benefited people from all walks of life. However, the development of inclusive finance still faces many problems and challenges.

\section{A. Coverage of Finance Service}

The number of financial institutions and the number of employees of financial institutions are important indicators of the level of inclusive financial development. With a wide network of financial institutions and a large number of employees, the supply of financial services is relatively good. Consumers and investors alike have greater access to diversified financial products and services, resulting in relatively high levels of inclusive finance. Therefore, a clear understanding of the development of inclusive finance in a region requires an analysis of the number of financial institution and employees in the region.

In recent years, the number of financial institutions in Chongqing and the number of employees has increased totally. Especially the number of financial employees per 10,000 square kilometer increased from 17437.5 in 2007 to 21868.93 in 2017 according to "Table I".

TABLE I. COVERAGE OF FINANCE SERVICE From 2013-2017

\begin{tabular}{|c|l|l|}
\hline \multirow{2}{*}{ Year } & \multicolumn{2}{|c|}{ Coverage of finance service } \\
\cline { 2 - 3 } & $\begin{array}{c}\text { Number of financial } \\
\text { institutions per 10,000 } \mathbf{k m}^{\mathbf{2}}\end{array}$ & $\begin{array}{c}\text { Number of financial } \\
\text { employees per 10,000 } \mathbf{~ m}^{2}\end{array}$ \\
\hline $\mathbf{2 0 1 3}$ & 278.1553 & 17437.50 \\
\hline $\mathbf{2 0 1 4}$ & 298.1796 & 18228.16 \\
\hline $\mathbf{2 0 1 5}$ & 312.3786 & 18434.47 \\
\hline $\mathbf{2 0 1 6}$ & 258.4951 & 20521.84 \\
\hline $\mathbf{2 0 1 7}$ & 266.8689 & 21868.93 \\
\hline
\end{tabular}




\section{B. Use of Financial Services}

In recent years, although financial supply has been increasing, only if financial services products are truly implemented in the hands of those who have a demand for inclusive financial services can they truly play an inclusive role. In order to further understand the development of inclusive finance, it is also necessary to analyze the relevant situation of financial products in Chongqing. At present, deposits and loans are the most basic and most representative inclusive financial services products, and they are also the key services of inclusive financial services.

In terms of deposit services, it is currently one of the essential financial services products. "Table II" shows that the demand for deposit services has been continuously met in Chongqing. The balance of various deposits has increased from 2,278.917 billion yuan in 2013 to 3485.353 billion yuan in 2017, an average annual increase of approximately 241.287 billion yuan.

On the loans side, in order to give full play to the structural guidance function of monetary policy tools, Chongqing Municipality focuses its work on areas such as peasant, with a deep focus on poverty, micro-enterprise financing, and so on. Table 2 shows that by the end of 2017 , the loan of financial institutions in Chongqing had reached $2,841,746$ million yuan, an increase of $11.34 \%$ over the previous year, and an increase of 104.177 billion yuan over 2013.

TABLE II. USE OF FINANCIAL SERVICES FROM 2013-2017

\begin{tabular}{|l|l|l|}
\hline \multirow{2}{*}{ Year } & \multicolumn{2}{|c|}{ Use of financial services } \\
\cline { 2 - 4 } & \multicolumn{1}{|c|}{ Deposit } & \multicolumn{1}{c|}{ Loans } \\
\hline $\mathbf{2 0 1 3}$ & 22789.17 & 18005.69 \\
\hline $\mathbf{2 0 1 4}$ & 25160.11115 & 20630.69452 \\
\hline $\mathbf{2 0 1 5}$ & 28778.8 & 22955.21 \\
\hline $\mathbf{2 0 1 6}$ & 32160.09 & 25524.17 \\
\hline $\mathbf{2 0 1 7}$ & 34853.53 & 28417.46 \\
\hline
\end{tabular}

\section{THE MEASUREMENT OF INCLUSIVE FINANCE}

At present, the construction of inclusive financial indicators is not uniform. This article mainly refers to the methods used by Wangjing and Huguohui (2013) to calculate the inclusive financial index. The measure index is constructed from the supply and demand angles, which is divided into two dimensions: the coverage of finance service and the use of financial services.

\section{A. Construction of Indicator System}

The coverage of finance is mainly expressed in terms of the number of financial institutions per 10,000 square kilometers, as well as the number of employees. The use of financial services is expressed by deposits and loans in GDP per capita, as shown in "Table III".
TABLE III. CONSTRUCTION OF INDICATOR SYSTEM

\begin{tabular}{|c|c|c|c|}
\hline Dimensions & $\begin{array}{c}\text { Descriptive } \\
\text { statistics }\end{array}$ & Indicators & $\begin{array}{c}\text { Indicator } \\
\text { code }\end{array}$ \\
\hline \multirow{2}{*}{$\begin{array}{c}\text { Coverage of } \\
\text { finance } \\
\text { service }\end{array}$} & $\begin{array}{l}\text { Number of } \\
\text { financial } \\
\text { institutions } \\
\text { per } 10,000 \\
\text { km }\end{array}$ & $\begin{array}{l}\text { Number of financial } \\
\text { institutions/area }\end{array}$ & d1 \\
\hline & $\begin{array}{l}\text { Number of } \\
\text { financial } \\
\text { employees } \\
\text { per } 10,000 \\
\mathrm{~km}^{2}\end{array}$ & $\begin{array}{l}\text { Number of financial } \\
\text { employees/area }\end{array}$ & $\mathrm{d} 2$ \\
\hline \multirow{2}{*}{$\begin{array}{c}\text { Use of } \\
\text { financial } \\
\text { services }\end{array}$} & $\begin{array}{l}\text { Use of } \\
\text { deposit }\end{array}$ & $\begin{array}{l}\text { Deposit per } \\
\text { capita/GDP per capita }\end{array}$ & $\mathrm{d} 3$ \\
\hline & Use of loan & $\begin{array}{l}\text { Loan per capita/GDP } \\
\text { per capita }\end{array}$ & $\mathrm{d} 4$ \\
\hline
\end{tabular}

\section{B. Method of Measurement}

Due to the differences in the dimensions and units, the results may be very different from the actual values. Therefore, the way to measure of inclusive finance mainly uses the variation coefficient method to calculate the weights of the indicators.

The coefficient of variation mainly refers to the ratio of the standard deviation to the average of an indicator, as shown in formula:

$$
V_{i}=\sigma_{i} / \bar{x}_{i}
$$

The weight of each indicator is calculated by the coefficient of variation, as shown in formula:

$$
w_{i}=V_{i} / \sum_{i=1}^{n} V_{i}
$$

Prior to the calculation of financial inclusion scores, the original values of each indicator need to be normalized, as shown in formula:

$$
d_{i}=w_{i} \cdot\left(x_{i}-\operatorname{Min}_{i}\right) /\left(\operatorname{Max}_{i}-\operatorname{Min}_{i}\right)
$$

The degree of financial development of inclusive finance IFI can be expressed, as shown in formula:

$$
I F I=1-\frac{\sqrt{\left(w_{1}-d_{1}\right)^{2}+\left(w_{2}-d_{2}\right)^{2}+\cdots+\left(w_{n}-d_{2}\right)^{2}}}{\sqrt{w_{1}^{2}+w_{2}^{2}+\cdots+w_{n}^{2}}}
$$




\section{The Result of Measurement of Inclusive Finance}

According to formula above, the development level of inclusive finance in Chongqing is measured. The specific results are shown in "Table IV".

TABLE IV. The RESUlt of MEASUREMENT OF INCLUSIVE FinANCE

\begin{tabular}{|c|c|c|c|c|c|}
\hline Year & d1 & d2 & d3 & d4 & IFI \\
\hline $\mathbf{2 0 1 3}$ & 0.1924 & 0.1261 & 0.0656 & 0.0640 & 0.7481 \\
\hline $\mathbf{2 0 1 4}$ & 0.2145 & 0.1391 & 0.0632 & 0.0609 & 0.8107 \\
\hline $\mathbf{2 0 1 5}$ & 0.2302 & 0.1424 & 0.0767 & 0.0718 & 0.8259 \\
\hline $\mathbf{2 0 1 6}$ & 0.1707 & 0.1767 & 0.0777 & 0.0714 & 0.7885 \\
\hline
\end{tabular}

Inclusive finance in Chongqing is at a steady stage of development and growth has slowed. With the development of information technology, during this period, coverage of finance service and the employees of financial institutions were merged and reduced, which led to a slowdown in the growth rate of the Inclusive Financial Development Index during this period. There was even a downward trend between 2015 and 2016.

From the perspective of the construction of the inclusive financial development index, the trend of the inclusive financial development index in Chongqing is quite consistent with the characteristics of each stage, but there are fluctuations, and there is still a large space for the development of inclusive finance in Chongqing.

\section{EMPIRICAL ANALYSIS}

In this part, it will set the variable and model. Then use STATA to regression. From the results, it will show the factor of the inclusive of finance in Chongqing China. That is the way to do the empirical analysis.

\section{A. Variable Settings}

Combined with the theoretical analysis of the impact on inclusive finance, this paper will carry out an empirical analysis of the factors that affect the development of inclusive finance from four aspects: economic development level, industrial structure, and urban-rural income gap and government financial expenditure. The specific variables are selected as follows.

The level of economic development is expressed in terms of A GDP. The measurement of the level of economic development in this article mainly uses the GDP per capita of Chongqing. Industrial Structure (Ind): The selection of industrial structure in this paper is mainly measured by the proportion of each industry to GDP. Urban and rural income gap (Gap): Mainly calculated using the ratio of disposable income of urban and rural residents in Chongqing. Government Fiscal Expenditure (Gov): Mainly measured by local public service fiscal expenditure in Chongqing.

\section{B. Model Settings}

Based on the selected variables, this paper takes the inclusive finance index as a dependent variable and constructs a multivariate linear regression model with the above four variables to conduct an empirical analysis of the factors affecting the inclusive finance. Specifically, the inclusive financial index obtained by taking the economic development level A GDP, the industrial pull rate Ind_1, Ind_2, Ind_3, the urban-rural income gap, and Gov as independent variables as the dependent variables, A measurement model of the impact factors of inclusive finance is established, and the specific model settings are shown in formula:

$$
\begin{aligned}
& I F I_{t}=\alpha+\beta_{1} A G D P_{t}+\beta_{2} \text { Ind_1 } 1_{t}+\beta_{2} \text { Ind_2 }{ }_{t} \\
& +\beta_{3} \text { Ind_3 }{ }_{t}+\beta_{4} \text { Gap }_{t}+\beta_{5} \text { Gov }_{t}+\mu
\end{aligned}
$$

Among them, $\beta_{\mathrm{i}}$ is the regression coefficient of each interpretation variable and is an error term. The results of the descriptive statistical analysis of the respective variables are shown in "Table V" below:

TABLE V. VARIABle Descriptive Statistics

\begin{tabular}{|c|l|l|l|l|}
\hline Variable & $\begin{array}{c}\text { Average } \\
\text { Value }\end{array}$ & $\begin{array}{c}\text { Standard } \\
\text { Error }\end{array}$ & Min & Max \\
\hline IFI & 0.5633 & 0.3005 & 0.0029 & 0.8257 \\
\hline Ind_I & 0.4636 & 0.2461 & 0.3 & 1.1 \\
\hline Ind_2 & 7.5727 & 2.3589 & 4.3 & 11.7 \\
\hline Ind_3 & 5.2909 & 0.5907 & 4.6 & 6.6 \\
\hline Gap & 3.0195 & 0.4168 & 2.5474 & 3.5878 \\
\hline LnGov & 7.7304 & 0.5886 & 6.6443 & 8.3748 \\
\hline
\end{tabular}

\section{The Results of Regression}

In the course of the empirical analysis, this paper uses the stepwise regression method, and uses STATA software to add the explanatory variables to the empirical regression one by one, and removes the variables with poor regression results. From the results, due to the relatively small number of sample observations, the model has a serious multiple caroline, so it is removed and the formula is adjusted to:

$$
\begin{aligned}
& I F I_{t}=\alpha+\beta_{1} A G D P_{t}+\beta_{2} I n d \_l_{t}+\beta_{3} I n d \_2_{t}+\beta_{4} G a p_{t} \\
& +\beta_{5} G o v_{t}+\mu
\end{aligned}
$$

Among them, $\beta \mathrm{i}$ is the regression coefficient of each interpretation variable and is an error term. The results of empirical regression are shown in "Table VI":

TABLE VI. ThE RESULT OF EMPIRICAL ANALYSIS

\begin{tabular}{|c|l|l|l|l|}
\hline Variable & $\begin{array}{c}\text { Coeffici } \\
\text { ent }\end{array}$ & $\begin{array}{c}\text { Standar } \\
\text { d Error }\end{array}$ & T Value & P Value \\
\hline Ind_I & -0.7014 & 0.1840 & -2.94 & 0.007 \\
\hline Gap & -0.3200 & 0.1086 & -3.81 & 0.005 \\
\hline Cons & 1.8545 & 0.2662 & 6.97 & 0.000 \\
\hline $\boldsymbol{R} 2$ & 0.9343 & Adj-R2 & 0.9179 & \\
\hline $\boldsymbol{F}(\mathbf{2}, \boldsymbol{8})$ & 56.90 & P $>$ F & 0.0000 & \\
\hline
\end{tabular}


According to the STATA results, the critical value of the $T$ value is analyzed, and the $P$ value in the empirical regression results, as well as the significant level, can be seen from "Table VI". The results of the empirical analysis reached 0.93 and 0.92 respectively. This shows that the multiple statistical regression fit is better, and the variables chosen can explain the reasons for the change of inclusive finance.

\section{CONCLUSION}

From the results of multiple statistical regressions (as can be seen in "Table VI"), it can be seen that the primary industry pull has a significant negative correlation with the development level of inclusive finance in Chongqing. On behalf of the primary industry is selected, thus indicating that traditional agriculture is not attractive to financial resources. Although the output value of the primary industry is now increasing year by year, due to the influence of the terrain, climate and water Conservancy conditions, the stability of the output value of traditional agriculture, forestry, animal husbandry and fishery is poor, and the commercial nature of finance is poor. Financial institutions are not so optimistic about the development of traditional agriculture, forestry, animal husbandry and fisheries that they are not willing to invest their funds in traditional agricultural industries that are relatively risky, leading to the serious commercialization of rural financial institutions. Rural financial resources flow more to the secondary and tertiary industries. Therefore, the stability of the annual output value of agriculture, forestry, animal husbandry and fishery is the main factor that affects the financial institutions' support for agriculture, forestry, animal husbandry and fishery. Accelerating the modernization level of agriculture can improve the stability of the annual output value of agriculture, forestry, animal husbandry and fishery, and thus enhance the attractiveness of agriculture, forestry, animal husbandry and fishery to financial resources.

The effect of urban and rural income gap on the development of inclusive finance has been significantly inhibited. The urban-rural income gap is negatively related to the inclusive financial index. The greater the income gap between urban and rural residents, the smaller the availability of financial services for township and rural residents. This is mainly due to the fact that with the widening of the urban-rural income gap, rural residents are gradually excluded from the financial system. Financial institutions will have a clear "bias" feature in the provision of financial services. In the background of the increasing gap between urban and rural areas, financial institutions will consider the corresponding risks in the provision of financial services. Because of their disadvantaged position, rural residents have greater difficulties in accessing financial services, which also inhibits the development of inclusive finance.

\section{REFERENCES}

[1] Tian Lin. Financial Inclusion: A New Development of Financial Geography in the Context of a New Crisis [J]. Economic Theory and Economic Management, 2013(01): 69-77.

[2] Wangjing, Hu Guohui. Development Evaluation and Impact Factors Analysis of China's Inclusive Finance [J]. Financial Forum, 2013, (06): 34 -36.

[3] Zhai Shuai. Research on the Inclusive Financial Index of Jiangsu Province and its affecting factors [J]. Accounting Monthly, 2015 (12). 65-69.

[4] Jiaojin, Huangtingting, Wangtian, Zhangshaohua, Wang Hao. China's Inclusive Financial Development Process and Empirical Research [J]. Shanghai Finance, 2015(04): 12-22.

[5] Zhang Yu, Zhao Min. Research on the Development Level and Influencing Factors of Rural Inclusive Finance: An Empirical Analysis Based on the Six Western Provinces [J]. East China Economic Management, 2017(03).

[6] Mostak.Ahamed.Does inclusive financial development matter for firms tax evasion?Evidence from developing countries $[\mathrm{J}]$. Economics Letters, 2016.

[7] Kempson E.Whyley C., Understanding and combating financia exclusion [J]. Insurance Tends, 1999, (21): 18-22. 